\title{
Corrigendum: Do congenital prosopagnosia and the other-race effect affect the same face recognition mechanisms?
}

\author{
Janina Esins ${ }^{1 *}$, Johannes Schultz ${ }^{1,2}$, Claudia Stemper ${ }^{3}$, Ingo Kennerknecht ${ }^{3}$, \\ Christian Wallraven ${ }^{4}$ and Isabelle Bülthoff ${ }^{1,4}$ \\ ${ }^{1}$ Department of Human Perception, Cognition and Action, Max Planck Institute for Biological Cybernetics, Tübingen, \\ Germany, ${ }^{2}$ Department of Psychology, Durham University, Durham, UK, ${ }^{3}$ Institute of Human Genetics, Westfälische \\ Wilhelms-Universität Münster, Münster, Germany, ${ }^{4}$ Department of Brain and Cognitive Engineering, Korea University, Seoul, \\ South Korea
}

Keywords: congenital prosopagnosia, other-race effect, face recognition, Asian, Caucasian

\section{A Corrigendum on}

Do congenital prosopagnosia and the other-race effect affect the same face recognition mechanisms?

Esins, J., Schultz, J., Wallraven, C., and Bülthoff, I. (2014). Front. Hum. Neurosci. 8:759. doi: 10.3389/fnhum.2014.00759

\section{OPEN ACCESS}

Edited by:

Guillaume A. Rousselet,

University of Glasgow, UK

${ }^{*}$ Correspondence: Janina Esins,

janina.esins@tuebingen.mpg.de

Received: 04 May 2015 Accepted: 08 May 2015 Published: 27 May 2015

Citation:

Esins J, Schultz J, Stemper C Kennerknecht I, Wallraven $C$ and Bülthoff I (2015) Corrigendum: Do congenital prosopagnosia and the other-race effect affect the same face recognition mechanisms?

Front. Hum. Neurosci. 9:294. doi: 10.3389/fnhum.2015.00294
The list of authors of this article should be corrected in order to include Ms. Claudia Stemper and Prof. Dr. Ingo Kennerknecht. Both authors have contributed significantly to this study. Almost all prosopagnosic subjects were ascertained by them. Therefore, the authorship order should be considered as follows:

Janina Esins ${ }^{1 *}$, Johannes Schultz ${ }^{1,2}$, Claudia Stemper ${ }^{3}$, Ingo Kennerknecht ${ }^{3}$, Christian Wallraven ${ }^{4}$ and Isabelle Bülthoff ${ }^{1,4}$

${ }^{1}$ Department of Human Perception, Cognition and Action, Max Planck Institute for Biological Cybernetics, Tübingen, Germany

2 Department of Psychology, Durham University, Durham, UK

${ }^{3}$ Institute of Human Genetics, Westfälische Wilhelms-Universität Münster, Münster, Germany

${ }^{4}$ Department of Brain and Cognitive Engineering, Korea University, Seoul, South Korea

The authors regret the error.

Conflict of Interest Statement: The authors declare that the research was conducted in the absence of any commercial or financial relationships that could be construed as a potential conflict of interest.

Copyright $\odot 2015$ Esins, Schultz, Stemper, Kennerknecht, Wallraven and Bülthoff. This is an open-access article distributed under the terms of the Creative Commons Attribution License (CC BY). The use, distribution or reproduction in other forums is permitted, provided the original author(s) or licensor are credited and that the original publication in this journal is cited, in accordance with accepted academic practice. No use, distribution or reproduction is permitted which does not comply with these terms. 